\title{
A COMMENT ON THE AMENDMENTS TO THE FEDERAL SECURITIES ACTS
}

\author{
Morris L. Forer $\dagger$
}

On August 10, 1954, the Securities Act Amendments Act ${ }^{1}$ was signed by the President and went into effect on October 10, 1954.

In a session of Congress that saw the enactment of a changed income tax law and the shifting basis of the role of investigating committees, the passing of what may be denominated as technical revisions $^{2}$ is of minor legislative moment. It is. And yet as a history of congressional and administrative interaction, ${ }^{3}$ and as a nostalgic reminder of the dynamic days of New Deal legislation, it has its interest

$\uparrow$ Member of the Philadelphia Bar.

1. 68 Stat. 683 (1954). Title I-Amendments to Securities Act of 1933, 48 Stat. 74 (1933), as amended, 15 U.S.C. $\$ 77 \mathrm{a}$ (1952) (amending $\$ \$ 2(3), 2(8)$, $2(10), 2(11), 3(a)(11), 4(1), 5,10,12,17(a), 22(a))$. Title II-Amendments to Securities Exchange Act of 1934, 48 STAT. 881 (1934), as amended, 15 U.S.C. $\$ 78 \mathrm{a}$ (1952) (amending $\$ \$ 11(\mathrm{~d}), 12(\mathrm{~d}))$. Title III-Amendments to Trust Indenture Act of 1939, 53 STAT. 1149 (1939), 15 U.S.C. \$77aaa (1952) (amending $\$ \$ 303(1), 303(2), 303(3), 303(4), 304(\mathrm{~b}), 305(\mathrm{c}), 306,324)$. Title IV-Amendments to Investment Company Act of 1940,54 Stat. 789 (1940), 15 U.S.C. $\$ 80 \mathrm{a}$ (1952) (amending $\$ \$ 2(a)(30), 24(\mathrm{~d})$, adding $\$ 24(\mathrm{e}))$.

2. The president of the New York Stock Exchange, G. Keith Funston, indicated to the Senate sub-committee conducting hearings on the amendments that the exchange would "like at some future date to present . . proposals which are not included in this present bill because they do not fall in the category of technical amendments." Hearings Before the Subcommittee on $S$. 2846 of the Senate Committec on Banking and Currency, 83d Cong., 2d Sess. 78 (1954). There is a quasiofficial tendency to minimize the importance of the amendments. Demmler \& Armstrong, The Federal Securities Law: The Scope and Effect of the Nete Amendments, 41 A.B.A.J. 133, 135 (1955); see also Sen. Hearings, supra at 31. (Mr. Demmler, chairman of the Securities and Exchange Commission, has recently resigned, and Mr. Armstrong, one of the commissioners, has been designated chairman.) But it is misleading to consider the 1954 amendments, to use a phrase of the empirical philosopher of the Securities Act, Benjamin V. Cohen, as merely "punctuation" amendments. The underlying amendments constitute a definite change in the law and not merely an attempt "to simplify and clarify" the then existing law, despite the many official statements to the contrary. See, e.g., Hearings Before the House Committee on Interstate and Foreign Commerce on H.R. 7550 and S. 2846, 83d Cong., 2d Sess. 11 (1954) ; 100 CoNg. Rec. 2343 (daily ed. March 2, 1954) ; 100 Cong. REC. 6060 (daily ed. May 11, 1954); 20 SEC ANn. Rep. 1 (1955); cf. N.Y. Times, May 30, 1954, \$3, p. 1, col. 6; id., \$3, p. 5, col. 2.

3. See Lobell, Revision of the Securities Act, 48 CoL. I. Rev. 313 (1948). Since the background of this interaction was covered by Lobell and in the contemporaneous writings of Professors Byse \& Bradley, Proposals To Ament The Registration and Prospectus Requirements of the Securities Act of 1933, 96 U. of PA. L. REv. 609 (1948), and in one of the master law books of our time, Loss, Securities Regulation (1951) (see Forer, Book Review, 100 U. of PA. L. Rev. 927 (1952)), the page proof of whose 1955 supplement the present writer was privileged to review before its issue, it is substantially omitted in this article. 
not only for the active practitioner in the securities field but also for the student of politics. ${ }^{4}$

The 1954 legislation constituted amendments to the important federal regulatory statutes ${ }^{5}$ involving the issue and sale of securities and administered by the Securities and Exchange Commission. ${ }^{6}$

The acts administered by the Commission, with the possible exception of the Public Utility Holding Company Act, ${ }^{7}$ reflect the philosophy of minimal federal ${ }^{8}$ governmental interference. ${ }^{9}$

The Securities Act, ${ }^{10}$ the first of the New Deal statutes dealing with securities, is a disclosure statute, sometimes known as "truth in securities" legislation. ${ }^{11}$ In the words of the present chairman of

4. Despite accusations flung at the present members of the "partially" bipartisan Commission (aggravated by its determination in such cases as the Dixon-Yates integration and capital structure questions: Mississippi Valley Generating Company, SEC, Summary of Holding Company Act Release 12794, Feb. 9, 1955, and by constant references to the wishes and philosophy of the Eisenhower Administration, when in fact the movement to amend the Securities Acts has reached at least its confirmation age (see Demmler \& Armstrong, supra note 2, at 133 ), the word "politics" is not used invidiously.

5. All the statutes directly administered by the SEC were amended with the exception of the Public Utility Holding Company Act, 49 Star. 803 (1935), 15 U.S.C. $\$ 79$ (1952).

6. The Securities Act as originally enacted provided in $\$ 2(5)$ for administration by the Federal Trade Commission, but 1934 amendments ( $\$ 210$ and 211, Title II of the Securities Exchange Act of 1934, 48 STAT. 908-09 (1934), 15 U.S.C. $\S \S 78 \mathrm{ii}-\mathrm{jj}$ (1952)) transferred to the SEC all powers, duties and functions of the FTC.

7. See note 5 supra. See Dean, Book Review, 50 MIcr. L. Rev. 1388, 1392 (1952). The Public Utility Holding Company Act, as such, was not affected by the act of 1954. During 1954, when Commission witnesses were appearing before the congressional committees, the Commission was considering an ill-advised, radical departure from Rule U-50 (in the application of which there had already been serious inroads), requiring competitive bidding in the sale of securities by registered holding companies and their subsidiaries. The chairman of the Commission found himself on the defensive with respect to administration of a statute not even being technically considered. House Hearings, supra note 2 , at 55 et seq. In its annual report the Commission casually dismissed the furor over Rule U-50. 20 SEC ANN. REP. 73-74 (1955).

8. There was no attempt by Congress in the Securities Act to pre-empt the securities field. In the states divers blue sky laws govern, although in amendments to the state statutes the procedures and concepts of the federal legislation were intercalated. See, e.g., Illinois Securities Law of 1953, Ill. AnN. Stat. c. 1211/2, $\$ \$ 137.1-137.19$ (Supp. 1954), and rules promulgated thereunder. The inadequacy of state legislation was, however, one prime argument for national legislation. See, e.g., Sen. Rep. No. 47, 73d Cong., 1st Sess. 2 (1933). The main reasons for such inadequacy were: ill-conceived and ineptly drafted statutes, limitation of their applicability, failure to provide for effective enforcement of such statutes, and the interstate character of twentieth century business which made the evasion of state blue sky laws an easy maneuver. U.S. Dep'T of Comarerce, A STUdy of THE Economic and Legal Aspects of the Proposed Federal Securtries Act, in Hearings Before the House Committee on Interstate and Foreign Commerce on H.R. 4314, 73d Cong., 1st Sess. 87, 100 (1933) ; Cherrington, The Investor and the SeCuritres ACr 54 et seq. (1942). These inadequacies still prevail to a great extent.

9. Cf. Loevinger, The Law of Free Enterprise 281 (1949); Report of Committee of American Bar Association on Federal Regulation of Securities, 10 THE Business Lawyer 73, 74 et seq. (Nov. 1954).

10. 48 SтAT. 74 (1933), 15 U.S.C. \$\$77a-aa (1952).

11. The interesting and compelling antecedents to this legislation are traced exhaustively by Loss, op. cit. supra note 3, c. 1,3 , and by a former commissioner 
the Commission, the act contains "requirements of disclosure by the issuer [of securities] through a prospectus, publicly distributed, reflecting information . . . in a registration statement officially filed." In addition, the act contains, and is based on, "the imposition of liability for misrepresentation and concealment in the registration statement and prospectus or in representations made by the seller." 12

Succinctly stated, the purposes of the act are "to prevent exploitation of the public by the sale of unsound, fraudulent and worthless securities through misrepresentation; to place adequate and true information before the investor; to protect honest enterprise, seeking capital by honest presentation, against the competition afforded by dishonest securities offered to the public through crooked promotion; to bring into productive channels of industry and development capital which has grown timid to the point of hoarding; and to aid in providing employment and restoring buying and consuming power." 13

To respond to the legislative and financial challenge and especially to provide dealers and investors with adequate information with respect to securities to be offered, the Securities Act, as in effect prior to the 1954 amendments, employed a facile mechanism. New issues of securities were to be registered. Unless a registration was in effect, it was to be unlawful publicly to offer for sale or to sell securities, except exempt securities, ${ }^{14}$ in interstate commerce or through the mails. During the period between the filing of the registration statement and the time it was to become effective (normally twenty days although the Commission was given the power to accelerate this effective date ${ }^{15}$ ), the information contained in the registration state-

of the SEC and at present head of the American Stock Exchange, McCormick, UNDERSTANDING THE SECURITIES ACT AND THE S.E.C. c. 1,2 (1948); see also Byse \& Bradley, supra note 3, at 609 n.2, for contemporary bibliographical references. The traumatic and seminal impact of the 1929 stock market crash on a legislative generation (going into 1955 with the Fulbright security market "study" investigation) has often been noted. Commissioner Armstrong, in a speech before the Association of the Bar of the City of New York, on December 6, 1954 summarized the principal contributing causes of the 1929 stock market crash (SEC Mimeo. p. 2). A recent judicial reference to security practices which led to the Securities Act is in the replete, yet disappointing, anti-trust opinion, United States v. Morgan, 118 F. Supp. 621, 636 et seq. (S.D.N.Y. 1953) ; see Steffen, The Investment Bankers Case: Some Observations, 64 Y $\mathrm{ALE}$ L.J. 169 (1954); Whitney, The Investment Bankers Case-Including a Reply to Professor Steffen, 64 YALE L.J. 319 (1955).

12. Demmler, Registration of Securities Under the Securities Act of 1933, 10 THE BusINEsS LAWYER 42, 43 (Nov. 1954).

13. 2 SEC ANN. REP. 1 (1936).

14. Section $3(\mathrm{a})$ provides a list of specifically exempted securities; \&3(b) allows the SEC to exempt issues that do not exceed $\$ 300,000$. See notes 56,57 infra. Section 4 provides that the registration requirements do not apply to certain exempted transactions. The broad scope of the word "security" $(\$ 2(1))$ is apparent from the exempted list; see note 60 infra.

15. This was effected by amendment attached to the bill on investment companies and became law on August 22,1940. The Commission's powér of acceleration is still being debated and further proposals to amend $\$ 8(a)$ were made before the President's signature on the 1954 amendments was dry. See Proceedings at the 
ment ${ }^{16}$ was to be widely disseminated. This registration of securities was to be effected by the issuer of the securities, which, by virtue of certain definitions, included persons in control of the issuing company. ${ }^{17}$ The more important information required in the registration statement was to be disseminated in the form of a "prospectus."

Section 5 of the act in substance prohibited offers to sell or sales of securities during the so-called waiting period and thereby made it unlawful to sell securities prior to the effective date of the registration statement. Under Section 2(3) of the Securities Act, "sale" was defined to include both offers to sell and sales.

In practice, dealers and underwriters, obsessed with the desire to minimize and distribute risk, and utilizing speed of investor commitment as an answer to this compulsion, chafed under the act. ${ }^{18}$ The chafing was less of an irritant than it might otherwise have been because of the constitutional limitation imposed upon Section 5 and the "oral loophole." 19 The chafing was exacerbated, on the other hand,

Annual Meeting of the Section of Corporation, Banking and Business Law of the American Bar Association, 10 THE Business LAWYER 51-53, 77-81 (Nov. 1954). It has even been suggested that the power to grant acceleration is of such great practical importance that discretionary failure to grant it would prohibit the public offering of almost any security. Id. at 78.

16. This was of a prescribed and full nature, relating to the securities, the company, the management, the purpose of the issue, together with financial statements, options, contracts and other data. See Neff, Forms for Registration of Securities under the Acts of 1933 and 1934, 51 HARV. L. REv. 1354, 1355 (1938).

17. The term "issuer" $(\$ 2(4))$ includes, in addition to an issuer of securities, any person, directly or indirectly, controlling or controlled by the issuer or any person under direct or indirect common control with the issuer, by virtue of its interpolation into the definition of "underwriter" in $\$ 2(11)$. Such a controlling person is not an issuer in other sections of the Securities Act. Apparently strained interpretations have evolved, but through a determined and somewhat strait-laced view, the Commission has been able to present a consistent statutory pattern. E.g., SEC Securities Act Release No. 97, pt. 4, Dec. 28, 1933, 11 FED. REG. 10951 (1946); Ira Haupt and Co., 23 S.E.C. $589^{\circ}$ (1946); Resources Corporation International, 7 S.E.C. 689 (1940); Thompson Ross Securities Co., 6 S.E.C. 1111 (1940); Sweet's Steel Co., 4 S.E.C. 589 (1939). To meet to a limited degree the Ira Haupt problem and administratively to clarify the $\$ 4(2)$ broker exemption problem, Rule 154 was amended in December, 1954. SEC Securities Act Release No. 3525, Dec. 22, 1954.

18. While the security industry's anticipation of the registration steps was apparently, and in varying degrees, not infrequent, the Commission throughout the years has gone very slowly and exceedingly mildly in ferreting out and punishing "jumping the gun"-a practice especially prevalent in boom times and one which often emanates from buyer pressure as well as seller. Commission castigation, as in Van Alstyne, Noel \& Co., 22 S.E.C. 176 (1946), has been of the slap-on-the-hand variety. Intramural action would usually be taken under the broker-dealer provisions of the Securities Exchange Act.

19. Constitutionally, Congress had clearly not exhausted its power over the offer and sale of securities in $\$ 5$. Cf. SEC v. Crude Oil Corp., 93 F.2d 844, 848-49 (7th Cir. 1937); Coplin v. United States, 88 F.2d 652, 656-57 (9th Cir. 1937); Jones v. SEC, 79 F.2d 617, 620 (2d Cir. 1935), rev'd on other grounds, 298 U.S. 1 (1936); SEC v. Torr, 15 F. Supp. 315, 319 (S.D.N.Y. 1936). Any nexus with the facilities of interstate commerce (or the "Post Offices") would have been sufficient to subject every part of the distribution of securities to federal regulation. There is, however, a severe legislative limitation which encompasses oral offers. Prior to the amendment, the prohibitions of $\$ 5$ were not applicable if the seller did not use the mails or channels of interstate commerce in making the offer. Subse- 
as the publicist moved in upon a securities industry which could not reap the fruits of any free-wheeling literature, as the lawyer appeared at the dealers' and underwriters' elbows and warned of the growing litigious success of the SEC and of investors, ${ }^{20}$ and as the Commission appeared in the guise of a conceptualistic scoffer demanding that underwriters, in a waiting period which became more and more of a cooling off period, ${ }^{21}$ give all the facts constituting or underlying an offer and yet not offer the securities. In practice, sellers of securities were hesitant to inform prospective customers during the waiting period about a proposed new issue for fear that such activity might be held to constitute an illegal offer ${ }^{22}$ and thereby involve substantial legal liabilities. The Commission recognized that the distinction between "dissemination of information" and an "offer" was not easy to draw and that such distinction was still more difficult for a lay customer to appreciate. ${ }^{23}$ What concerned the Commission in trying to carry out the purposes of the statute was that the objective of wide-spread dissemination of information during a waiting period was not more effectively achieved.

In the counterpoise of the interests of capital development and of the corporate form of business (reflecting means and ability to concentrate economic power in itself) ${ }^{24}$ and of those of protection for the investor or potential investor, the balance required constant surveillance. The Commission attempted, within the statutory framework, to harmonize speed and facility in obtaining capital funds in a twentieth century enterprise ${ }^{25}$ with full protection for the increasing number of investors. ${ }^{26}$ In its job of economic reconciliation under the power delegated to it and of making the statutory enactment better reflect "the dictates of economic laws . . . discovered by observation ...

quent to the effectiveness of the registered securities, an oral offering could be made even in interstate commerce. This was sometimes known as the "oral loophole." Byse \& Bradley, supra note 3, at 616-17.

20. See 19 SEC ANn. Rep. 13-17, 99-106, 145, 158, 163-65 (1954); 10 SEC ANn. REP. 22-29, 185-88, 190-92, 280-94, 308-14 (1945); 5 SEC ANN. REP. 95-117, 132, 191-93, 235-57 (1940).

21. See Lobell, supra note 3 , at 318.

22. It has been suggested that this articulated fear may have been claimed "with tongue in cheek." Lobell, supra note 3, at 325. Demmler and Armstrong highlight the fear, tying it into the statute's criminal sanctions and the purchaser's right of rescission for one year, under $\$ 12(1)$. Demmler \& Armstrong, supra note 2, at 134. Senator Bush on the floor of the Senate called the waiting period one of "considerable confusion and considerable doubt regarding the rights of an underwriter . . offering . . securities." 100 Cong. Rec. 2343 (daily ed. March 2, 1954).

23. Sen. Hearings, supra note 2 , at 24.

24. See Berle, The 20th Century Capitalist Revolution 25 (1954).

25. See McCormick, Understanding the Securttres ACt and the S.E.C. 287 (1948).

26. See Kimmel, Share Ownership in the United States passim (1952). 
worked out through human experience," ${ }^{27}$ the Commission took repeated administrative actions designed to encourage issuers and underwriters to make available to dealers and prospective investors, during the waiting period, the information which the statute intended that they should have. ${ }^{28}$ Thus, the distribution during the waiting period of summaries of information in the registration statement prepared by independent investment services ${ }^{29}$ was sanctioned and the distribution of so-called "red herring prospectuses" 30 and of identifying statements ${ }^{31}$ to dealers was required. To permit and encourage the use of these informal documents, the Commission issued opinions and provided by rules ${ }^{32}$ that their use did not necessarily constitute an offer which could not be lawfully made prior to the effective date of the registration statement under the then existing law. Despite these official pronouncements, it is common knowledge that the basic information contained in registration statements was not publicized adequately during the waiting period, as had been originally contemplated.

In this setting it may be astonishing that attacks on the Securities Act and companion legislation were not more frontal..$^{33}$ Early amendments had, however, taken care of some of the legislative interstices, and companion statutes filled hiatuses. ${ }^{34}$ There was general confidence 1954).

27. See Pound, An Introduction to the Philosophy of Law 29 (rev. ed.

28. See Demmler \& Armstrong, supra note 2, at 134.

29. SEC Securities Act Release No. 464, Aug. 19, 1935, 11 Fed. Reg. 10954 (1946) ; id., No. 802, May 23, 1936, 11 FED. Reg. 10957 (1946). Standard \& Poor's "blue cards" were a popular form of such summaries.

30. "Red herring" prospectuses derived their name from a legend in red ink superimposed on each page of the prospectus to the effect that a registration statement had been filed but had not yet become effective, that the information in the document was subject to correction and change, that the circular was not to be considered an offer to sell or a solicitation of an offer to buy, and that no offer to buy or sell should be made or offer accepted until the effective date. See Sen. Hearings, supra note 2 , at 24 .

31. SEC Securities Act Release No. 3447, 17 FED. REG. 6566 (1952); id. No. 3453, 17 FED. REG. 8898 (1952).

32. See last sentence of $\S 19$ (a) (48 Stat. 85 (1933), as amended, 15 U.S.C. $\$ 77 s(a)(1952)$ ) to the effect that no provision of the Securities Act shall apply to any act done or omitted in good faith in conformity with any rule or regulation of the Commission, even if such rule is later amended, rescinded or determined to be invalid.

33. One reason was that socio-economic group conflict was not intensified, as, perhaps, in the case of the National Labor Relations Act, 49 Stat. 449 (1935), as amended, 29 U.S.C. \$\$151-66 (1952).

34. Practitioners have always referred in official English to the statute as: the Securities Act of 1933, as amended. It was first amended in 1934, 48 STAT. 905 (1934), when the following sections were changed: $\$ \$ 2(1), 2(4), 2(10), 3$ (a) (2), $3(\mathrm{a})(9), 3(\mathrm{a})(10), 3(\mathrm{a})(11), 4(1)$, former $4(3), 10(\mathrm{~b})(1), 11(\mathrm{a}), 11(\mathrm{~b})$, 11(c), 11(e), and 13. The Motor Carrier Act of 1935 broadened the exemption in $\S 3(a)(6)$ to cover any security used by a common or contract carrier and issued subject to the provisions of $\$ 20$ a of the Interstate Commerce Act. 49 STAT. 557 (1935). In 1945 a major amendment to $\$ 3(\mathrm{~b}), 59$ STAT. 167 (1945), substituted " $\$ 300,000$ " for " $\$ 100,000$ " in the authority of the Commission to exempt small issues of securities from the registration requirements of the act. Reference will be made to the abortive amendment of 1954 in this regard. See text following note 55 and notes 42,56 , and 57 infra. 
in the integrity and reasonableness of the administering agency and in its undertakings to attempt to deal realistically with the problem. The resistance to uprooting amendments was natural. This inhibition was due partly to a 1929 stock market crash neurosis. ${ }^{35}$ Yet in this frame of legislative-administrative reference, the movement for more radical amendment to close the gap between congressional theory and capitalist practice gained momentum. ${ }^{36}$

In May, 1940, broad amendment bills were introduced. When Commission comment was requested, Jerome Frank (then Chairman and now a judge of the United States Court of Appeals for the Second Circuit) suggested that the hearings be postponed to give the Commission and representatives of the securities industry an opportunity to see whether and to what extent they could agree on proposals. Conferences resulted in a suggested amendment to Section 8(a) which would have authorized the Commission to accelerate the twenty-day waiting period. ${ }^{37}$

In the summer of 1940, two securities industry associations and the two leading exchanges appointed a committee which, with a Commission staff committee, examined the provisions of the Securities Act and the Securities Exchange Act. The end result was the submission to Congress in the summer of 1941 of separate Commission and industry reports. ${ }^{38}$ Extensive hearings were held, but the impetus for amendment was sunk with the attack on Pearl Harbor. ${ }^{39}$

In addition the following provisions of the Federal Bankruptcy Act have constituted in turn and in effect amendments to the Securities Act: $\$ 264$ of Chapter $X$, 52 Stat. 902 (1938), 11 U.S.C. $\$ 664$ (1952); $\$ 393$ of Chapter XI, 52 Stat. 914 (1938), 11 U.S.C. \$793 (1952); and \$518 of Chapter XII, 52 STAT. 928 (1938), 11 U.S.C. $\$ 918$ (1952); as well as $\$ 77(\mathrm{f}), 49$ STAT. 920 (1935), 11 U.S.C. $\$ 205(\mathrm{f})$ (1952). Section 304(a) (5) of the Trust Indenture Act of 1939, 53 STAт. 1153 (1939), 15 U.S.C. \$77ddd(a) (5) (1952), and \$24(d) of the Investment Company Act of 1940, 54 STAT. 825 (1940), 15 U.S.C. \$80a-24(d) (1952), may also be considered amendments.

35. This has carried over into the 1955 Fulbright investigation. Hearings on Factors Affecting the Buying and Selling of Equity Securities Before the Senate Committee on Banking and Currency, 84th Cong., 1st Sess. 1, 2, 20, 35, 251, 254 et seq. (1955). See also note 11 supra.

36. See, e.g., Creamer, Capital and Output Trends in Manufacturing INDUSTRIES, 1880-1948, at 62 (1954).

37. See note 15 supra.

38. Altogether there were eighty-six proposed amendments. Forty-eight related specifically to the Securities Act. There was agreement on thirty-three of these between the industry and the Commission. There were, however, important areas of disagreement (especially relating to $\$ \S 14$ and 16 of the Securities Exchange Act). See SEC, Report on Proposals for Amendments to tee Securities Act of 1933 and The Securitres Exchange Act of 1934 (1941); IBA, NASD, N.Y. Curb Exchange \& N.Y. Stock Exchange Report on the Conferences with the Securities and Exchange Commission and its StafF on Proposals for AMENDing the Securrties Act of 1933 aNd the Securities Exchange Act of 1934 (1940).

39. See Final Report of the Securitues and Exchange Commission SubCommittee to the House Conimittee on Interstate and Foreign Comarerce, 82d 
In 1947, a new Commission staff committee initiated "a somewhat less ambitious" program: ${ }^{40}$ to resolve in practical operation the statute's objectives that accurate information be disseminated among the investors as soon as possible and that no investors commit themselves until they have had a fair opportunity to consider the full and relevant data (in a statutory prospectus). The Commission published an outline of tentative proposals for revising Section $5,{ }^{41}$ but the amendatory legislation died aborning.

As a lineal descendant of the 1947 proposals, and as the progeny of an at times uneasy, continued symbiosis of government and industry, ${ }^{42}$ the 1954 amendments were born.

The basic changes incorporated in the Securities Act Amendments Act of 1954 permit written offers to sell securities during the

Cong. 139 (1952). The Heller subcommittee more than ten years later stated quite properly that "all parties feit that the major problem of the solicitation of offers, the use of the prospectus, and related complexities of Section 5 of the 1933 act should be approached and solved first ..." and complained that failure to reach even tentative understanding resulted in no cohesive proposal for amendment to the subcommittee. Ibid. The SEC in its 1941 proposals did not affirmatively urge any $\$ 5$ changes. It did, however, consider a compromise approach which while preserving the statutory scheme would (as part of it) insure the investor's receipt of a full prospectus before committing himself. This approach would require the investor to have the complete prospectus for a reasonable period of time before binding himself to take the securities. A twenty-four hour locus poenitentiae was conceived. Thus, it was contemplated that the investor would receive a statutory prospectus complete in every respect, except for the material usually contained in the price amendment (normally filed a day or so before the effective date) on (or just before) the effective date. This would cause the twenty-four hour period to begin running. The underwriter or dealer, upon the effective date, could give the purchaser the omitted information orally and then supply it in writing later and at this point take the firm commitment. The complete selling document was to be "made to serve its primary function." SEC, REPORT ON PROPOSALS FOR AMENDMENTS TO THE SECURTTIES ACT OF 1933 AND THE Securittes ExChaNGe ACT OF 1934, at 10 (1941). Industry worked out a rescission proposal. Sales could be made upon the effective date. One business day later a statutory prospectus would be received. The investor would be permitted to rescind, or as some opponents to the proposal in castigating it called the right of the investor, "to welsh." IBA, NASD, N.Y. CURB EXCHANGE, N.Y. Stock Exchange, op. cit. supra note 38.

40. Loss, op. cit. supra note 3 , at 248 .

41. At almost precisely the same time two painstaking, intensive, and corrective analyses of the problems encountered under the Securities Act, legislative solutions, and especially these proposals, were published: Byse \& Bradley, supra note 3; Lobell, supra note 3 . With these dissertations and Loss' book accessible, the arduous routing of industry and Commission proposals (with the SEC becoming more pliant and flexible, in the direction of the industry's 1941 proposal) seems supererogatory.

42. On January 27, 1954, Senator Capehart, Chairman of the Committee on Banking and Currency, and Representative Wolverton, Chairman of the Committee on Interstate and Foreign Commerce, introduced companion bills to amend provisions of the acts administered by the Commission. The next day President Eisenhower in his economic report stated: "The federal securities laws were enacted nearly twenty years ago and have remained largely unchanged over the period. Some modifications in these laws are needed which, while fully protecting the interests of investors, will make the capital market more accessible to businesses of moderate size. It will also be desirable to simplify the rules and thus reduce the cost of registration of new issues and their subsequent distribution." Sen. Hearings, sitpro note 2 , at 1 . The bill was passed on the Senate's consent calendar on March 2 , 1954. It then went to the House Committee on Interstate and Foreign Com- 
statutory period (after a registration statement has been filed with the SEC but before it has become effective) by means of a prospectus filed with the Securities and Exchange Commission prior to its use. This change (bringing in tow the dichotomization of "offer" from "sale" 43 and the harbinger of more readable prospectuses through summary forms ${ }^{44}$ ) has been heralded as removing the difficult concept of the pre-October, 1954 practice: that it was permissive (and even obligatory under Commission administration) for an issuer or underwriter to disseminate information during the waiting period but that it was illegal to offer or solicit offers. ${ }^{45}$ Permit offers during the waiting period-is the new "direction" 46 from Congress to its specialized agency. No change was made as to sales or contracts of sale or contracts to sell securities; these are still illegal prior to the effective date of the registration statement.

Other changes are of tangential significance. Thus, the unrealistic, mandatory requirement in the Securities Act that a dealer must deliver a prospectus in the initial distribution of a security (regardless of how long the distribution took) and in trading transactions for one year after the registration statement became effective ${ }^{47}$ was amended, so that delivery is now required during the actual offering period but in no event less than forty days after the effective date of the commencement of the public offering, whichever expires later.

merce which reported the bill favorably, except for a proposal to amend $\S 3(\mathrm{~b})$ of the Securities Act to increase the Commission's power to exempt small issues from $\$ 300,000$ to $\$ 500,000$. With the $\$ 300,000$ limit, the bill was passed without dissenting vote in either house. As the Commission analyzed it during the fall of 1953, they received and considered thirteen principal suggestions for amendments. See Appendix at pp. 1039-40 infra.

43. Section 1 of the Securities Act Amendments Act (note 1 supra) amends $\$ 2(3)$ to redefine the term "sale," in order to distinguish between "offers and sales." The redefinition of "sale" required formal amendments to various sections of the Act ( $\$ \S 2(11), 3(\mathrm{a})(11), 12,17(\mathrm{a})$, and 22(a)) to insert the term "offer" to preserve existing law with respect to those particular sections. The existing exception from the term "sale" for preliminary negotiations and agreements between an issuer and an underwriter was revised to give effect to pre-amendment interpretations to cover negotiations and agreements between a controlling person and an underwriter prior to the filing of the registration statement.

44. Section $10(\mathrm{~b})$. Generally lawyers have been the authors of prospectuses, and accordingly these documents have suffered from the usual turgidity of a profession obsessed by a superabundance of caution and agglutinative precedent.

45. This language has almost become a cliche in the legislative history documentation of the amendments. See, e.g., Sen. Hearings, supra note 2 , at $6 ; 20$ SEC ANN. REP. 2 (1955).

46. See Gilbert \& Kampelman, Legislative Control of the Bureaucracy, 292 ANNALS 76, 78 (1954), adopting semantics of HYNEMAN, BUREAUCRACY IN A DEMOCRACY c.1 (1950).

47. Section 5(b) required and now requires that all persons use statutory prospectuses in connection with the sale of a registered security. The third clause of $\S 4(1)$ exempted dealers from the requirements of $\$ 5$, except under two sets of circumstances: any dealer not a participant in the distribution, as such, must use the 
However, certain types of investment companies which continuously offer securities were required to use prospectuses over a longer period. ${ }^{48}$

Again, prospectuses used for longer than thirteen months required, before the 1954 amendments, information more recent than prospectuses used for shorter periods. In order to equalize the requirements, the act was amended to provide that, where a prospectus is used for more than nine months after the effective date, the information contained in the prospectus must be of a date within sixteen months of such use.

Turning to the Securities Exchange Act, ${ }^{49}$ Congress felt that the prohibition against the extension of credit by dealers to purchasers of new issues for six months after the offering period was unduly long. The amendment reduced the six-month period to thirty days. ${ }^{.0}$ An ambiguity as to when-issued trading was also eliminated. ${ }^{51}$

The Trust Indenture Act of $1939,{ }^{52}$ which required inclusion in a prospectus of a summary of certain specified indenture provisions, was amended to permit greater latitude to the Commission. ${ }^{53}$ This was

prospectus as to all transactions in the registered securities within one year from the beginning of the offering; any dealer who participated in the distribution was required to continue to use the prospectus in connection with the disposition of his portion of the registered issue of securities being distributed even though the one year period had expired. It had long been maintained that the one year period should be reduced. The 1947 tentative staff proposal had limited the period to three months.

48. Securities offered by open end management companies or unit investment trusts: $\$ 24(\mathrm{~d})$ of the Investment Company Act, 54 STat. 825 (1940), 15 U.S.C. $\$ 80 \mathrm{a}-24$ (d) (1952). Normally such companies register once a year. Thus, if the reduction to forty days were to apply, independent dealers in such securities would have been limited to a considerably shorter time with respect to the use of prospectuses than dealers engaged in distribution. See Sen. Hearings, supra note 2 , at 90.

49. 48 STAт. 881 (1934), as amended, 15 U.S.C. \$78a (1952).

50. Section 11(d)(1), which was the subject of the amendment, has been a troublesome provision of the Securities Exchange Act although it had a laudable purpose of segregating the broker-dealer function in the same person and of trying to provide for placement of new issues with "investors rather than speculators." H.R. Rep. No. 1542, 83d Cong., 2d Sess. 15, 27 (1954); see also Sen. Rep. No. 1036, 83d Cong., 2d Sess. 18 (1954); H.R. Rep. No. 1383, 73d Cong., 2d Sess. 22 (1934); Sen. Rep. No. 792, 73d Cong., 2d Sess. 12 (1934). Further legislative clarification of $\S 11$ (d) (1) would have been useful.

51. The last two sentences of $\S 12$ (d) of the Securities Exchange Act had dealt with the subject of when-issued trading (trading in unissued securities effected in contemplation of their issuance) on exchanges. The first of these sentences provided ample and general authority under the homogenized but useful standard of public interest and protection of investors used throughout the statute. The last sentence represented an attempt to deal with the problem somewhat more precisely and in language that, it had long been felt, was not completely apposite. See Loss \& Vernon, When-Issued Securities Trading in Law and Practice, 54 YALE L.J. 741, 766 et seq. (1945).

52. 53 STAT. 1149 (1939), 15 U.S.C. \$77aaa (1952).

53. The categorical language of $\S 305(\mathrm{c})$ of the Trust Indenture Act, 53 STAT. 1154 (1939), 15 U.S.C. \&77eee(c) (1952), had been considered a possible obstacle to the Commission's power under $\S 10$ of the Securities Act to allow shorter prospectuses (involving in this instance, debt securities). But see Form S-9, SEC 
done also to obviate the criticism as to over-long and unduly complicated prospectuses in the offerings of what is known commonly as the institutional type of debt securities.

An amendment to the Investment Company Act of $1940^{54}$ permitted investment companies which engage in continuous offering of their shares to file an amendment to their registration statements each year instead of filing new registration statements. ${ }^{55}$

One amendment to the Securities Act, proposed by the administration, the Commission, the industry, and initially at least by the committees of both houses of Congress was not enacted. In the Securities Act as first passed and as in effect until 1945, the Commission had authority to exempt small issues up to $\$ 100,000$ from the provisions of the act. This permissive amendment contained in Section 3 (b) of the act was in addition to the "automatic" exemptions and also in addition to the exclusions directly provided in the act. In 1945 the act was amended to permit exemptions of issues up to $\$ 300,000 .^{56}$ The amendatory proposal, whittled down from some requests made for a higher ceiling, was for $\$ 500,000$. Despite the phalanx of support buttressed by impressive witnesses, statistics as to flotation costs, price indices, cajoling and cogent arguments, Congress was not ready to relax to such a degree the safeguards considered to reside in the fuller scrutiny and administrative involvement of a registration. ${ }^{5 \tau}$

Securities Act Release No. 3503, May 27, 1954; SEN. REP. No. 1036, 83d Cong., 2d Sess. 19 (1954); H.R. REP. No. 1542, 83d Cong., 2d Sess. (1954). See note 44 supra.

54. 54 StAT. 847 (1940), 15 U.S.C. \$80a (1952).

55. Section 24(e), as added by the 1954 amendments, see note 1 supra; SEN. Rer. No. 1036, 83d Cong., 2d Sess. 21 (1954); H.R. Rep. No. 1542, 83d Cong., 2d Sess. 30 (1954).

56. 59 STAT. 167 (1945), 15 U.S.C. $\$ 77 \mathrm{c}($ b) (1952); see note 42 supra.

57. See, e.g., Sen. Hearings, supra note 2 , at 1, 5, 9, 11, 13, 18, 26, 34-54, 62, $71-74,82,84-85,92-97,102-07,123$. The principal industry proponents for expansion of the Commission's exemptive power were the independent telephone companies, who urged a $\$ 600,000$ limit (see note 42 supra). The amendment was urged as facilitating public financing by small business, by minimizing the expense of issuing securities as compared with a "full" registration and thus making public interstate offerings a mode of financing more competitive with private placements. It was maintained that the amendment would not affect existing Commission authority to adopt safeguards, in the form of required offering circulars, subject to civil liabilities under $\$ \$ 12$ and 17 of the act for deficiencies or inaccuracies and by order, to suspend or deny the exemption because of fraud, threatened fraud, or other violation of the statute or of rules or regulations.

Almost the only debate on the Securities Act amendments occurred with respect to these provisions. Thus, the present Speaker, Mr. Rayburn, stated after an encomium on the Securities Act: "But I do think that when people want to issue securities up to $\$ 500,000$, that is a lot of money for the unsuspecting public to go out and buy. I think when it goes above $\$ 300,000$ they should be compelled to go to the . Commission and lay down their financial situation. . . I have always feared that the time would come when someone would start whittling away the salient provisions of these bills. . . . But I do think in the interest of the American 
With this synopsis of the action (and the one major non-action) taken in 1954, more microscopic analysis is required of the legislative texture. This can best be studied by minutely considering the impact of the amendments upon the keystone provision of the Securities Act, Section 5.58

investors and in the interest of sound financing of our corporations that it is dangerous, very dangerous, for us to raise this amount to more than $\$ 300,000$." 100 CoNG. REC. 6107 (daily ed. May 12, 1954).

Representative Bennett, of Michigan, also objected, citing figures that: "In a three month period last year $\$ 21$ million of these promotional and speculative stocks were sold under this $\$ 300,000$ exemption. That adds up to about eighty-five or eightysix million dollars a year. . . If you increase this exemption to $\$ 500,000$, then you nearly double that $\$ 86$ million and thereby aggravate the present situation, which is none too healthy at the present time. It is not a question of whether you should do something for small business. If you are going to balance the equities in this instance between small business and the small investor, certainly you have to resolve all doubts in favor of the small investor because he is the fellow who is putting up the money." 100 Cong. Rec. 6108 (daily ed. May 12, 1954).

The balance of interest has been well stated. The greatest protection that must be accorded is in precisely the small issues. Because of their small size and because of the desire to keep down expenses, there is often less legal and accounting scrutiny than might otherwise be proper, and that is required in registrations. By the empirical working of the securities industry more completely speculative issues are put out under $\$ 300,000$ than above. The Commission has with commendable zeal in recent years tried to reduce expenses of registration. With the expertise of an increasing segment of the bar in these matters, the cost also should decrease. The effect of such expertise is not only in reduced legal fees but, in addition, in the exceedingly important item of printing costs. The difference between copies and printer's proofs can mount into thousands of dollars. The expertise of counsel is also shown in the ability to allocate expenses so as to maximize legally the amount of deductible legal expenses. Despite a contrary feeling in the investment industry, the exchanges, and members of the present staff of the Commission who recommended such a change, it is submitted that the grass root objection had strong validity. The able eponymous chairman of the Fulbright Committee tentatively considered as one of two possible new pieces of legislation in the securities regulatory field that might be necessary a provision calling for "greater disclosure of corporate facts by companies issuing stock under Regulation A, under $\$ 3(\mathrm{~b})$." N.Y. Times, March 14, 1955, p. 1, col. 8; id., p. 20, col. 4; see also Sen. Hearings, supra note 35 , at 382 .

58. Section 5 now provides as follows:

Sec. 5. (a) Unless a registration statement is in effect as to a security, it shall be unlawful for any person, directly or indirectly-

(1) to make use of any means or instruments of transportation or communication in interstate commerce or of the mails to sell such security through the use or medium of any prosepectus or otherwise; or

(2) to carry or cause to be carried through the mails or in interstate commerce, by any means or instruments of transportation, any such security for the purpose of sale or for delivery after sale.

(b) It shall be unlawful for any person, directly or indirectly-

(1) to make use of any means or instruments of transportation or communication in interstate commerce or of the mails to carry or transmit any prosepectus relating to any security with respect to which a registration statement has been filed under this title, unless such prospectus meets the requirements of section 10 ; or

(2) to carry or to cause to be carried through the mails or in interstate commerce any such security for the purpose of sale or for delivery after sale, unless accompanied or preceded by a prospectus that meets the requirements of subsection (a) of section 10.

(c) It shall be unlawful for any person, directly or indirectly, to make use of any means or instruments of transportation or communication in interstate 
As amended in 1954, Section 5 of the Securities Act partitions (albeit inartistically) the registration process into three stages: the pre-filing, the waiting period (between the filing of the registration statement and its effective date), and the post-effective stages. ${ }^{59}$

The new Section 5 (c) provides that, before a registration statement has been filed with the Commission, any use of interstate facilities or the mails to "offer to sell or offer to buy" any security ${ }^{80}$ is prohibited. Also prior to filing, Section 5 (a) prohibits sales or deliveries of the securities. ${ }^{61}$ The term "sale" as now defined by Section 2 (3) includes "every contract of sale or disposition of a security or interest in a security, for value." Thus, before a registration statement is filed, interstate facilities or the mails cannot be used in any way to distribute or further the distribution of a non-exempt security.

Section 5(b) (1) applies during the waiting period. This section prohibits the use of interstate facilities or the mails to transmit any "prospectus" unless it meets the requirements of Section 10, which in turn prescribes the contents of the statutory prospectus. Since the term "prospectus" is defined by Section $2(10)$ to mean a written offer $^{62}$ (with certain few exceptions), there is thus no prohibition against oral offers even by interstate telephone during this period, as there is before the filing. As defined and supplemented by rule and interpretation, the written offer during the waiting period can be made by a so-called tombstone ad, ${ }^{63}$ a preliminary prospectus not dissimilar

commerce or of the mails to offer to sell or offer to buy through the use or medium of any prosepectus or otherwise any security, unless a registration statement has been filed as to such security, or while the registration statement is the subject of a refusal order or stop order or (prior to the effective date of the registration statement) any public proceeding or examination under section 8.

59. This trichotomy is also adopted by Loss, Supplement to Securities ReguLATION (1955).

60. The term "offer to sell" is defined in $\S 2(3)$ to include every attempt or offer to dispose of, or solicitation of an offer to buy, a security or interest in a security, for value. The definition of security in $\$ 2(1)$ is not a restricted one. See, e.g., SEC v. W. J. Howey Co., 328 U.S. 293 (1946); SEC v. C. M. Joiner Leasing Corp., 320 U.S. 344 (1943) ; United States v. Reidel, 126 F.2d 81 (7th Cir. 1942); SEC v. Universal Service Ass'n, 106 F.2d 232 (7th Cir. 1939), cert. denied, 308 U.S. 622 (1940); Corporation Trust Co. v. Logan, 52 F. Supp. 999 (D. Del. 1943); SEC v. Associated Gas and Electric Co., 24 F. Supp. 899 (S.D.N.Y. 1938).

61. As can be noted, $\$ 5(a)$ in fact prohibits sales or deliveries of securities at any time before the effective date of the registration statement.

62. An offer on radio or television is also included.

63. Section 2(10) (b) provides that a notice, circular, advertisement, letter or communication regarding a security is not to be deemed a prospectus if it states from whom a $\$ 10$ statutory prospectus may be obtained and, in addition, does no more than identify or state the security, the price, by whom orders will be executed and such other information as the Commission may permit. Advertisements under this clause are known as tombstone ads. The tombstone ad, not designed as selling literature, but only as a screening device for prospective customers sufficiently interested in a particular security to ask for a statutory prospectus, is usually inserted in newspapers but may be displayed otherwise. Until the 1954 amendments, a tomb- 
to the former "red-herring prospectuses," ${ }^{64}$ a new summary prospectus, as well, theoretically, as by the complete statutory prospectus. During the waiting period, specific prohibitions remain. As will be noted, amended Section 5, sub-section (b) (1), prohibits transmission of any other written offers during the waiting period; sub-section (a) prohibits selling ${ }^{65}$ or delivering securities (in the same manner as in the pre-filing stage); and sub-section (c) prohibits making offers otherwise sanctioned while any public examination or proceeding looking toward a Commission stop order or refusal order under Section 8 is pending or operative.

There is no limitation on oral offers during the waiting period. ${ }^{86}$ Prior to October 10,1954, oral offers over interstate telephone lines could be made only after the effective date; now they can be made freely during the waiting period. Since most offers in any event can be and are made in this manner, ${ }^{67}$ the complex tripartite mechanism of offer by prospectus and sale may be reduced in some part to an interesting academic footnote. The Commission and critics of the widened loophole were cognizant of the danger to the whole statutory scheme which the relaxing amendment effected, but alternatives in the form of monitoring oral communications (vide: wire tapping) were less palatable and a counterattack might have endangered the entire legislative program.

After the effective date, sales may be freely made through prospectuses. This is substantially different from the sanctioned activities during the waiting period. ${ }^{68}$ By virtue of Section $2(10)$, the term "prospectus" as defined after the effective date permits supplemental selling literature (that is, literature accompanied or preceded by a full Section 10 prospectus).$^{69}$ In any event, the full prospectus must pre-

stone ad could not be used before the effective date. Its exclusion from the definition of prospectus did not, however, make it less of an attempt to dispose of a security and, hence, within the pre-1954 definition of "sale." See proposed adoption of Rule 134, SEC Securities Act Release No. 3535, 20 FED. REg. 1067 (1955).

64. See note 30 supra.

65. A sale made before the effective date without use of mails or interstate facilities is not illegal, but the sending of a confirmation through the mails or interstate facilities would through the brigaded interpretation of $\$ 5(\mathrm{~b})(1)$ and $\$ 2$ (10) constitute a violation if occurring before the effective date. As to confirmations, cf. Rule X-17A-3 (especially (a) (9)) SEC Securities Exchange Act Release No. 2304, Nov. 13, 1939.

66. See note 19 supra.

67. See Byse \& Bradley, supra note 3 , at $617 \&$ n.38.

68. By virtue of $\$ 5(\mathrm{~b})(2)$, unless the buyer has already received from some source (seller, issuer, underwriter or dealer) a full $\S 10$ (a) prospectus, delivery of the securities through the mails or in interstate commerce is illegal. The buyer's prior receipt of a $\S 10(b)$ prospectus will not satisfy the specific language of $\$ 5$ (b) (2). See also Rule 433, SEC Securities Act Release No. 3519, Oct. 12, 1954 , as limiting preliminary prospectuses to the purposes of $\S 5(\mathrm{~b})(1)$ during the waiting period.

69. This article will not traverse the fascinating terrain of newspaper, television and radio comment, inspired or uninspired. Patently a directly paid advertisement 
cede or accompany any interstate or mail delivery of the securities under Section 5(b) (2), and the actual entry of a stop order bars the use of interstate facilities or the mails even to make offers. ${ }^{70}$

The Commission has taken administrative action to complement the 1954 Congressional action. Thus far its most publicized action has been in promulgating a new Rule $433^{71}$ vice the much publicized redherring regulation Rule $131 .^{72}$ Under the imprimatur of Section 10 (b) directing the SEC to adopt rules permitting the use of an abbreviated or summary prospectus, the Commission's new rule merely provides that:

"A . . . prospectus filed as a part of the registration statement shall be deemed to meet the requirements of section $10 .$. . for the purpose of section $5(\mathrm{~b})(1)$. . . prior to the effective date . . provided the following conditions are met:

"(a) Such . . . prospectus contains substantially the information required by the Act and the rules . . . to be included in a prospectus meeting the requirements of section $10(\mathrm{a})$. . . or contains substantially that information except for the omission of information with respect to the offering price, underwriting discounts or commissions, discounts or commissions to dealers, amount of proceeds, conversion rates, call prices, or other matters dependent upon the offering price, and (b) The outside front cover page of such . . . prospectus shall bear, in red ink, the caption 'Preliminary Prospectus', the date of its issuance, and the following statement printed in type as large as that generally in the body . . . :

"A registration statement relating to these securities has been filed with the Securities and Exchange Commission, but has not yet become effective. Information contained herein is subject to completion or amendment. These securities may not be sold nor may offers to buy be accepted prior to the time the registration statement becomes effective. This prospectus shall not constitute an offer to sell or the solicitation of an offer to buy in any State in which such offer or solicitation would be unlawful prior to registration or qualification under the securities laws thereof."

Concurrently with the adoption of this Rule 433, the Commission codified its 1952 restatement of acceleration policy in a new Rule

is covered by the interdictions of the statute. Just as clearly a bona fide news report or account is not. The range in between, confused by arguments of freedom of speech and of press, demands attention-an intriguing problem not here challenged. Cf. Sen. Hearings, supra note 35 , at $679-82,928$.

70. The mere pendency after the effective date of a proceeding or examination under $\$ 8$ does not have this effect as it does during the waiting period.

71. SEC Securities Act Release No. 3519, Oct. 12, 1954. 1947.

72. SEC Securities Act Release No. 3177, Dec. 5, 1946; id. No. 3240, July 10, 
$460,{ }^{73}$ to the effect that the Commission, in ruling upon requests for acceleration of the effective date of a registration statement and in that regard the adequacy of public information respecting the issuer, will consider whether reasonable steps have been taken to make the information contained in the registration statement conveniently available to underwriters and dealers, who it is anticipated will be invited to participate in the distribution of the security.

There is the limitation that prospectuses would not have to be distributed in states where such distribution would be illegal-a realization of the break in federal-state harmony, which will be referred to later in this article. ${ }^{74}$

From the point of the extra-administrative sanctions, a more scrutinizing glance must be directed at the prospectuses to be disseminated during the waiting period. While the summary prospectus is filed with the registration statement, it is not deemed part of the registration statement for the purposes of the civil liability under Section $11 .{ }^{75}$ The exception from Section 11, designed mainly to encourage the widespread use of summary prospectuses, was justified on a number of grounds. "[D] eficiencies in such condensed prospectuses, if observed at the time of the Commission's processing of the registration statement and if material, may be dealt with administratively by the Commission under existing authority by requiring the material to be corrected and re-circulated with the changes noted. The official Section 10(a) prospectus has to be delivered to the buyer at or before the time he receives the securities. Finally, any deficiency in summary material which, despite the Commission's processing, might carry through to and occur in the Section 10 (a) prospectus will create liability under Section 11." 76 Administratively, the summary prospectus does remain subject to a Commission stop order. Then, too, it also is subject to the general provisions of Sections 12(2) and 17(a) and to the expanding concept of the seemingly ecumenical rules promulgated under Section 10(b) of the Securities Exchange Act. ${ }^{77}$ It has been remarked that there is this ironic twist: the issuer and the underwriters who are responsible for what goes into the summary prospectus are exempt from civil liability under Section 11 , but by this legislative

73. SEC Securities Act Release No. 3519, Oct. 12, 1954; id. No. 3536, 20 FED. REG. 1067 (1955).

74: See text at note 82 infra.

75. Section $10(\mathrm{~b})$.

76. House Hearings, supra note 2 , at 40 .

77. See Forer, Book Review, 100 U. of PA. L. Rev. 927, 929-31 (1952). Cases arising under Rule X-10B-5 are increasing. See 20 SEC ANN. REP. 49 and tables 13, 14 (1955). See also Latty, The Aggrieved Buyer or Seller or Holder of Shares in a Close Corporation under the S.E.C. Statutes, 18 LAW \& CoNTEMP. Prob. 505 (1953). 
scheme civil liability is imposed under Section 12(2) "upon the dealer who will have to use the summary prospectus (if at all) as he finds it." 78

The 1954 amendments do not eliminate other statutory and practical problems but often ease them. Thus, preliminary negotiations of the issuer with underwriters or "among underwriters who are or [who] are to be in privity of contract with [an] issuer" were and are permitted as an exception under Section 2(3) from the definitions of the terms "sale," "offer to sell," as well as the term "offer to buy" -as used in Section $5(\mathrm{c})$. The actual organization of the selling group is advanced, in statutory theory, from the effective date of the registration statement to the filing date. The question as to what the exception in Section 2(3) encompasses is still not clear. ${ }^{79}$ In practice the Commission has never interfered with the making of firm contracts between issuer and underwriter, and practitioners have always included the underwriting data prior to the effective date. The 1954 amendment of Section 2(3) codifies two Commission interpretations. These included agreements among underwriters to which the issuer was not a party ${ }^{80}$ and stretched the definition of issuer in Section $2(3)$ to the persons defined as issuer solely for Section 2(11), thus encompassing secondary distributions by persons in control. While the spreading of underwriters' market risk through extended preliminary negotiations is to be welcomed, apparently it may not be catapulted into a legalized jumping the gun device. ${ }^{.1}$

Another problem involves the permissibility of when-issued trading. Section 5 (c) prohibits offers on a when-issued basis by issuers, underwriters or dealers before the filing date. Before the 1954 amendments, Section $5(\mathrm{~b})$, which permitted such trading after the effective date (during whatever interval might elapse before the actual issuance of the securities), prevented sale except by complying with the prospectus requirement of that section; and it was no excuse that copies

78. Loss, Supplement to Securtties Regulation 75 (1955).

79. Prior to the 1954 amendments, this exception presented an even greater potential for avoidance of the full thrust of $\S 5$ on the securities industry's normal activities than it does now, but it is still clear that with the 1954 amendments the organization of the selling group must be delayed until the registration statement has been filed. The offer-to-buy prohibition was originally inserted to prevent dealers from making offers to buy during the waiting period or, as $\$ 5$ has now been amended, before the filing of the registration statement. In the 1954 amendments, the words "or offer to buy" were removed to the new $\S 5$ (c) so as to prevent dealers from being committed to underwriters or the issuer before obtaining adequate factual data. Parenthetically, the statutory scheme is such that an ordinary investor may make an offer to buy a security from the issuer or an underwriter or a dealer before the filing date, although no person in these three categories may solicit or accept his offer or make any attempt to sell to him.

80. On the theory that the managing underwriter negotiated with the others as agent for the issuer.

81. See note 18 supra. 
of the statutory prospectus might not have been made available by the issuer. Since the 1954 amendments, this is equally true of any offers on a when-issued basis, which may be made at any time after the filing date, as well as any contracts on a when-issued basis which may be made after the effective date. It is, of course, unlawful to make any contracts during the waiting period.

To turn to problems de hors the statute itself, the 1954 amendments and rules promulgated thereunder have broken the evolving federal-state coordination. Blue sky laws were patterned in general upon procedures of the federal agency. ${ }^{82}$ There has been manifest a reluctance on the part of state commissions to permit offers to be made prior to the effective date, either because their statutes are entirely clear and forbid them or because state commissions exhibit certain residual resentment or reluctance to move whenever the federal legislation moves. ${ }^{83}$ Various studies have been instituted looking to passage of model state securities acts and to bring them within the permissive provisions of the 1954 amendments. ${ }^{84}$ Unless this is done, the securities industry may find that the amendments have become a burden instead of an aid.

State agencies demonstrate ambivalence between maintaining the integrity of their evolved direction and pliability with respect to making the federal-state pattern work. Thus, as a viable compromise, the Secretary of State of Georgia has issued a rule permitting any dealer or issuer to advertise freely "but strictly stating that it is not an offer for sale. I did this to aid all concerns in following the changing regulations by the Federal Securities Act." ${ }^{85}$ This is followed by a naturally unreconstructed, individualistic caveat: "I would like to call your attention to one fact, although every effort is made to administer the Securities Act of the State in such a way that it will not make a hardship on anyone the Securities Act of Georgia is a separate and distinct Act from the Federal Securities Act. The State administrators of the various states' Securities Acts are finding it very

82. The new Illinois Securities Act, ILL. ANN. STAT. c.1211/2, \$\$137.1-137.19 (Supp. 1954), was patterned after the Federal Securities Act prior to the 1954 amendments. See An Examination of the New Illinois Blue Sky Law, 49 Nw. U.L. REv. 781,787 (1955). On definition of "sale" and "sell" see $\$ 137.2-\mathrm{E}$ of the Illinois Securities Law of 1953 ; cf. $\$ 2(3)$ of the Securities Act. One major difference is that the federal act excludes from the definition of "sales" preliminary agreements and negotiations between an issuer and underwriter; the Illinois statute does not. In Illinois the actual organization of the selling group is not permitted until the registration becomes effective.

83. See Letters from the Commissions of nineteen states to the law firm of author.

84. Loss, The Harvard Law School Study of State Securities Regulation, 5 Harv. L. School Bull. No. 6 (1954).

85. Letter from Ben W. Forston, Jr., Secretary of State of Georgia, to the author, November 30,1954 , on file Biddle Law Library, University of Pennsylvania Law School. See note 82 supra. 
necessary in order to protect the public to maintain an independence from the Federal Securities Commission." 86

A number of legislatures of affected states do not convene until next year; ${ }^{87}$ in other states the expert body shows no present inclination to request legislative change. ${ }^{88}$

The past attempts to achieve some degree of uniformity, as reflected in the action of the National Conference of Commissioners on Uniform State Laws of the American Bar Association in approving a Uniform Sale of Securities Act in $1929,{ }^{89}$ with the advances made through the National Association of Securities Administrators, must now be in part re-channeled. At the present time, work is proceeding on a model statute to be drafted in several parts corresponding to the divers regulatory philosophies. It has been suggested that one part might deal with fraud, one with broker-dealer registration, and one with securities registration. A fourth might contain general provisions essential under any of the schemes of state regulation. One of the desiderata must now be to key as far as practical any uniform state statute with the federal enactment. Whether and to what extent the state laboratory of social and economic experiment will, willy-nilly, subsume itself to a hegemony of federal regulations cannot be solved solely by the test of what is good for a securities company of underwriters is necessarily good for the individual state or its investors. In its thinking and even in its desire to cooperate, the individual state administrators may use as the test for the solution of their problems their consideration of the continued integrity and zeal of the federal agency.

The purpose of the Securities Act amendments was limited. They are by their very nature a half-way measure, raising practical, theoretical, and potentially litigious questions while solving others. With only dwarf-like steps do they expedite the effectuation of the purposes of federal securities regulation. Yet they do answer a basic complaint of the securities industry-at least the articulated complaint short of scuttling the Securities Act and permitting commitments without statutory prospectuses prior to the effectiveness of the registration. Much remains to be done. But their passage does exhibit political interaction, involving compromise of government and business, without surrender to or the complete satisfaction of either.

86. Ibid.

87. E.g., Mississippi, Minnesota, Virginia.

88. E.g., Missouri, Ưtah, California, New Mexico. See note 82 supra. The new Pennsylvania administration does not contemplate amendment of the Commonwealth's statute in the present biennium.

89. HANDBOOK OF THE NAT'L CONFERENCE OF COMMISSIONERS ON UNIFORM State Laws and Proceedings 171-204 (1929). 


\section{APPENDIX}

Suggested Amendanents to the Securities Act of 1933 and the Securities Exchange Act of 1934 Received by the SEC*

Amendments of the Securities Act of 1933 to . . . .

1. Permit the making of offers, but not of sales during the waiting period. ...

2. Reduce from 1 year to 30 days the period during which all dealers, whether or not participants in the initial distribution of a new issue, are required to deliver prospectuses in connection with trading transactions in the new issue.

3. Permit continuous and simplified registration of shares by investment companies which continuously offer shares to the public and require prospectuses to be delivered in trading transactions in outstanding openend investment company securities so long as securities of the same class are being offered to the public.

4. Simplify the registration and prospectus requirements . . of high-grade bonds.

5. Restore the broker's exemption as provided in Section 4(2) . . so as to give relief from the popular interpretation of the opinion of the Commission in . . Ira Haupt \& Co., 23 S.E.C. 589 (1946).

6. Exempt from registration outstanding shares of a listed stock being offered in connection with an employee stock purchase plan and simplify further the registration requirements of unissued shares of a listed stock being so offered.

7. Exempt from registration all securities .. . registered under the Securities Exchange Act of 1934 and dealt in for more than 3 years on a registered national securities exchange, and exempt additional issues of such securities.

8. Exempt from the prospectus requirements brokerage transactions in listed securities when the sale is made on an agency basis and agent's compensation is disclosed to and paid by the buyer.

* Hearings Before the Subcommittee on $S .2846$ of the Senate Committee on Banking and Currency, 83d Cong., 2d Sess. 4-5 (1954) ; Hearings Before the House Committee on Interstate and Foreign Commerce on H.R. 7550 and S. 2846, 83 Cong., 2d Sess. 13-14 (1954). 
Amendments of the Securities Exchange Act of 1934 to . . . .

9. Prohibit the extension of credit by a broker-dealer to a customer on a new issue of securities only if broker-dealer sold the securities to the customer or purchased the securities for the customer on a solicited order, and only while broker-dealer was engaged in the distribution of the securities and for 4 days thereafter.

10. Reduce the waiting period from 30 days to 10 days between the filing and effectiveness of applications for registration of additional issues of listed securities and remove restrictions on registration for when issued trading and with respect to securities to be issued or sold in connection with a reorganization under the Public Utility Holding Company Act or the Railroad Reorganization Act.

11. Amend $\S 16(b)$ to limit profits recoverable on behalf of a corporation from officers, directors, and 10 percent stockholders in short swing trading in the corporation's stock, . . . [thus] to provide a statutory limit upon liability smaller in amount than now permitted by the courts in construing the statutory term profits realized.

12. Require the Commission to proceed by order rather than by rule or regulation if [it] changes a rule of a national securities exchange to afford the exchange the right to a court appeal.

Amendment of the Investment Advisers Act of 1940 to . . . .

13. Permit general use of the title Investment Counsel by persons registered as investment advisers even though not primarily engaged in the rendering of investment supervisory services. 